\title{
Categories of everyday knowledge in German professional discourse
}

\author{
Natalia Shnyakina ${ }^{1}$, Anna Klyoster ${ }^{2, *}$ \\ ${ }^{1}$ Omsk State Pedagogical University, Department of German and Cross-cultural Communication, 644099 Omsk, Russia \\ ${ }^{2}$ Omsk State Technical University, Foreign Languages Department, 644050 Omsk, Russia
}

\begin{abstract}
The study of language as a cognitive phenomenon makes it possible to identify patterns of categorical division of the world. This paper considers the issue of the characteristics of everyday knowledge categories verbalization in professional discourse. On the basis of language fragments, objectifying ideas about the cognitive situation, through frame analysis, surface realizations of significant cognitive categories are investigated, among which are the subject of cognition, the object, the cognitive action, the instrument, the result, space and time. The named semantic nodes form the categorical structure of the frame behind the language fragment. The analysis demonstrates the compatibility of everyday and scientific knowledge division by a speaker; still, it illustrates the specificity of the language expression of frame nodes within the framework of professional discourse.
\end{abstract}

\section{Introduction}

Categorization is a basic cognitive process structuring the whole body of person knowledge about the world around him. In the process of vital activity, knowable phenomena are summarized under the categorical net underlying speech-thinking acts known to all members of the linguistic group. Objectification, presented in a text, fixes knowledge of various types corresponding to the generally accepted norms. This article examines the question of everyday knowledge categories objectification features in professional discourse, exemplified in the German language. Description of the indicated problem presupposes the study of the following aspects: the ratio of everyday and scientific knowledge in the world view of a native speaker; categorical segmentation of the cognitive situation as a result of the generalization of the situational knowledge frame nodes; specifics of surface implementations of everyday ideas in a professional text.

\section{Knowledge reflections in the linguistic world view}

The linguistic world view is person's knowledge objectivized in a symbolic form about the reality surrounding him, a kind of world view characteristic of a people, associated with the geographical, historical and cultural features of its existence. Traditionally, linguists distinguish the conceptual picture of the world as the inner informational content of human consciousness and the linguistic world view verbalizing this content [1-4]. The study of mental content through its objectification is the main focus of research undertaken in cognitive linguistics [5-8]; of particular interest are the patterns of expression in the language of various types of knowledge, the allocation of which depends on what meaning is embedded in this concept.

In philosophical works, knowledge is understood as "selective, ordered, in a certain way (method), obtained, in accordance with some criteria, formalized information that has social significance and is recognized as knowledge by certain social actors and society as a whole" [9, p. 392]. According to the level of functioning, knowledge is subdivided into scientific (special, rational, true knowledge, theoretical, reliable) and unscientific (sensual, knowledge in opinion, empirical, probabilistic, doxic, non-scientific, ordinary) [9, pp. 392-393]. Unscientific knowledge can include not only ordinary, everyday ideas, but also "fantasies, delusions, beliefs, convictions, prejudices, emotions, moral decisions", etc. [10, p. 19]. In linguistics, there are also attempts to identify types of knowledge that have something in common with the types distinguished in philosophy. On the one hand, knowledge can be both pre-scientific (everyday, based on common sense), artistic, representing an aesthetic way of learning the reality, and scientific, embedded in the system of concepts of any particular or general science. On the other hand, knowledge is divided into theoretical, based on a system of scientific abstractions, and practical, representing the result of practical activity [11, p. 109]. Linguistic understanding of the types of knowledge is based on the fact of their objectification in the field of professional and everyday communication between people.

Scientific knowledge is realized in professional discourse, understood by E. I. Golovanova as "verbally mediated communication as a process of controlled

*Corresponding author: annaklyoster@mail.ru 
interaction of subjects of professional activity, characterized by a certain set of norms, stereotypes of thinking and behaviour" [12]. These norms and stereotypes are expressed in the language and are recorded in various formats of written speech, including a monograph, an article, a dissertation work, a scientific or educational prose (textbooks, educational and methodical manuals, etc.), professional and technical works (instructions, safety regulations, etc.), patents, annotations, abstracts, etc. Oral speech is realized in the forms of a monologue (report, performance at a seminar lesson, oral review or oral review, defence of course and final qualifying works) and dialogue (scientific discussion and scientific conversation) [13]. Everyday knowledge, in turn, is not related to any particular subject area; it is realized in oral or written text: artistic, publicistic, as well as in everyday communication acts. Ordinary knowledge as a person naive view of the world is based on direct observations of a native speaker, in other words, the careful study of reality.

The view of the world, fixed in the language, includes various types of knowledge: both everyday and scientific. However, as many researchers believe, the lexical meaning of a word reflects an ordinary world view: naive representations of a native speaker play a decisive role in the process of forming linguistic meanings, and accordingly, a picture of the world [14]. In the field of professional communication, greater accuracy is required, so a scientific text is characterized by its peculiarities in the expression of information. Despite the similarity of the categorical representation of language fragments objectifying the naive and scientific ideas of a person about reality, the specific means of verbalizing the categories of ordinary consciousness should be noted. Their study implies the presentation of the methodological foundations of comparing the main headings of human experience with their superficial realizations at the level of a scientific text.

\section{Categorical frame structure of the cognitive situation}

General patterns of categorical division of the surrounding world manifest themselves in various types of discourse; they can be studied at the level of a language fragment, objectifying knowledge about the cognitive situation. As a method to compare the structuring of scientific and everyday representations of a person, frame analysis is used in the work. It is based on the general frame theory of M. Minsky [15, p. 355], according to which “... a person, trying to understand a new situation or to take a fresh look at familiar things, chooses from his memory a certain data structure (image), which we call a frame, so that by changing the individual parts in it we can make it suitable for understanding a wider class of phenomena and processes" [15, p. 357].

The interaction of the universal frame structure of the situation with the newly perceived data is based on the comparison of the "prototype frame" and the "frame instance". A "prototype frame" is a typical person's knowledge of a certain type of situation, a kind of stereotype that includes a set of nodes that are related to global mental categories and are understood after M. Minsky [15] as the "top nodes" of a frame. In the process of imposing relevant information perceived on one of the "prototype frames" in mind, it is filled with specific information, which contributes to the formation of a "frame instance" that is implemented in the language fragment. The relationship between the "prototype frame" and the "instance frame" is explained by the inclusion of private ideas about the significant rubrics of human experience in the system of a single categorical net, the presence of which in the human mind ensures the processes of speech recognition and speech generation. Frame analysis allows us to describe the specifics of the objectification of a person's understanding of the cognitive situation as a set of possible language realizations due to the communicative situation. This research procedure includes several stages: identification of significant elements in the language fragment, sequential analysis of their lexical meaning, interpretation of the general meaning of these elements taking into account the pragmatic focus of the statement [16]. The movement from the particular to the general is a logical operation of generalization, as a result of which a set of categorical components is revealed, reflecting the structuring of information about the cognitive situation.

In linguistics, attempts were made to identify such fundamental meanings. The foundations of such studies were laid by C. Fillmore, who spoke about the existence in the human mind of the deep cases that make up the situation structure ("who did something", "who something happened to", and "what underwent some change") [7, pp. 405-406]. Later, similar headings of experience were considered in [16, 17], where situational knowledge was understood as a structure containing logically interrelated elements. Summarizing the views expressed, we can consider the most significant categorical nodes that form the frame of the cognitive situation. Among them are the subject, the object, the cognitive action, the instrument, the result of cognition, space and time. The named top nodes of the situational knowledge frame represent an ideal structure reflecting the stereotypical model of the cognitive situation. The "prototype frame", being a complex unit of the content level, "grows" with specific details when implemented in the language fragment and is verbalized in a particular way in a particular subject area.

\section{Realization of categories of everyday knowledge in a professional text}

The unity of the categorical division of reality is manifested in texts of various orientations. The categories of everyday knowledge that form the top nodes of the "prototype frame" of a cognitive situation are specified in the scientific discourse in a particular way. This is due to the peculiarities of the professional text construction, on the one hand, and the specifics of the functioning of terms in it, on the other. 
The basic principles of organizing a professional text are consistency, coherence, integrity, and accuracy. The features of professional knowledge structuring are caused not only by the subject of speech, but also by non-linguistic factors that are included in the structure of the communicative situation: the knowledge fund of the subject of speech and the addressee, the degree of dedication to the subject of speech, belonging to a certain professional field of activity, time and space frameworks of professional communication. The use of special terminology in the professional text is its main feature [18-22]. Any linguistic fragment that reflects a person's views within a science, including an excerpt from a highly specialized text describing a cognitive situation, contains terms nominating components of professional reality. The term, acting as a central element of the utterance, exists in the minimal sufficient context in which its cognitive-heuristic potential is realized [20]. This context, often in the form of a single sentence, should be considered as a communicative unit, sufficient to understand the subject situation and its complete reconstruction.

The main feature of filling the frame top nodes due to the situation information is the unambiguous interpretation of what was said and the accuracy of the presentation. The specificity of the use of terms in a professional text imposes certain restrictions on language means, which act as the frame categorial elements objectifications of a cognitive situation. Comparative of these tools allows you to identify patterns of verbalization of everyday and professional ideas.

The category "subject" is an idea of a knowing active person, interacting with an object, and is expressed by a household or noun or pronoun, denoting a person or an animal:

- Die Jungen hören zu, nicken eifrig, stellen Fragen, wann es losgehe, wohin, wie.

- Ob Anneliese ähnlich schamlos in meinen Schubladen schnüffelt, wenn ich nicht zu Hause bin?

- Draußen auf dem Gang sprang ein Hund auf sie $z u$, bellte, beroch ihre Füße, die Hände.

In professional knowledge, this coordinate is represented by the names of the person, in which his professional affiliation or occupation, the place in the system of hierarchical relations or the communicative role in the cognitive situation is explicitly expressed:

- Der Ingenieur soll schnell das Nötigste finden und anschließend in der passenden Situation benutzen.

- Herr Prof. Dr. Hartmut Wandke untersucht das Verhältnis von Mensch und Technik.

- Die Benutzer erreichen Zufriedenheit und Kontrolle über die Anwendungssysteme, weil sie Aktionen auslösen, die sie kontrollieren und deren Ergebnisse voraussehen können.

The specifics of the "object" categorical coordinate specification are realized in a variety of verbalization of those elements of reality, to which the cognitive activity of a subject of a cognitive situation can be directed. Therefore, any object of surrounding reality has perceptual signs perceived by the subject functions as an "object of knowledge": Ich sehe einen Baum und sage Baum, ich rieche Kuchen, den meine Mutter am Sonntag bäckt, und sage Kuchen, ich höre einen Vogel im Garten zwitschern, und meine Mutter sagt: Ja, ein Vogel.

The expression of knowledge about an object in a professional discourse is not limited to the usual objects of the real world: Die Psychologen untersuchen das Thermalwasser und behaupten, dass es eine wirkungsvolle "Medizin" beim Stressabbau ist. Often the considered coordinate is implemented in nouns - the names of technical installations or abstract entities:

- $\quad$ Die Operatoren rüsten ihre eigenen Konsolen aus und prüfen sie bedarfsmäßig.

- Der Außenoperator beschaut die Anlage, um sie anhand von Anzeichen zu überwachen und um vor Ort auch an den Stellteilen eingreifen zu können.

- Am Endgerät untersucht man die Daten mittels geeigneter Programme.

The process of cognition has a strategic nature and through language objectifications in the context gives information about the channel for the acquisition of perceptual knowledge. In German, there are not only verbs of perception of general semantics, but also special verbs in which the channel of perception is fixed:

- $\quad$ Ich höre die Leute reden, die dort sitzen, höre, wie sie die Zeitung umblättern, mein Blick weißgebrannt von der Sonne.

- Mein Zimmer ist schattig, weil die Jalousien heruntergelassen sind, aber wäre das Fenster geöffnet, könnte ich, wenn ich die Augen aufmache, von meinem Bett aus die brennenden Berge sehen.

- $\quad$ Sie betastete prüfend ihr hochgestecktes Haar und stopfte eine Strähne, die ihr über die Schläfe fiel, in das Geflecht aus dunklen, dichten Haarschlangen zurück.

- Ich roch an dem Papier, dessen holziger, spröder Geruch eine Spur von dem cremigen Duft verriet, den ich bei unserm letzten Kuss geschmeckt hatte.

The forms of the cognition method objectification in professional discourse are determined by the variety of mental actions aimed at processing information of various types. Special text, as a rule, contains verbs indicating internal mental operations:

- Ein Experte soll die Aufmerksamkeit vom Arbeitnehmer untersuchen.

- Optische Signale, die im Gesichtsfeld des Beobachters erscheinen, sollen sofort entdeckt werden.

- Die Ingenieurpsychologen testen unter mehreren Exemplaren von einem Gerät auf Benutzerfreundlichkeit.

The categorical coordinate "instrument" in everyday knowledge is objectified by nouns nominating human organs performing perceptual actions (a nose, eyes, ears, skin, and a tongue):

- Jedes Mal, wenn wir Luft holen, gelangen Duftstoffe in unsere Nase.

- So habe ich denn auch das Meer, mit Augen gesehen und bin auf der schönen Tenne, die es weichend zurücklässt, ihm nachgegangen.

- Meine Ohren ertrugen nicht, dass meine Stimme ohne Training schlechter wurde.

- Er trägt zugleich dazu bei, dass wir eine heiße Herdplatte als schmerzhaft empfinden und einen Sonnenbrand auf der Haut spüren. 
- Malt-Liebhaber möchten ihren Whisky nicht nur auf der Zunge schmecken, sondern zuvor auch im Glas schimmern sehen.

In addition, the considered semantic node is often implemented by pointing to the human brain as the most complete organ of the internal processing of perceptual information: Über der Stuhllehne hängt die Jacke, in deren linker Tasche Eszter eine gelbe Packung Javaanse Jongens findet, voller Vorfreude riecht sie daran, und obwohl die luftdichte Verpackung nichts durchlässt, hat sie den Duft sofort im Gehirn.

In professional discourse, the implementation of the prototype frame has a special character. Along with the previously mentioned knowledge of the organs of perception, language means should be noted, which contain information about special technical devices that are related to human perception channels:

- Durch das Auge vermittelter Sinneseindruck führt beim Betrachter zu einer Empfindung namens Farbrelevanz.

- Sprachaudiometer verwenden gesprochene Sprache, um die Verständlichkeit abhängig von der Lautstärke zu messen.

- Die Pulte bilden die übliche konstruktive Ausführung von Leitständen, in denen Anzeiger eingebaut sind.

The demonstrated examples confirm the fact that a part of the cognitive functions in professional knowledge is performed by special machines and devices. Despite the fact that the position of a grammatical subject can be occupied by a word denoting a technical device intended for the cognition of the surrounding reality manifestations by a person, for example, a Sprachaudiometer, knowledge of this device actually corresponds to the element of the global categorical net "tool"; The "subject" remains unexpressed.

Spatio-temporal frameworks are significant aspects of the cognitive situation. Their reflection in everyday and professional knowledge can be called identical. The categorical coordinate "time" has several forms of manifestation: localization, repetition and length are most common. These forms of temporal relations are objectified in ordinary and professional text with the help of special temporal language units, reflecting both exact and approximate information about the temporal aspect of the cognitive situation.

The implementation of these aspects in everyday knowledge can be demonstrated in the following examples:

- Heute sehe ich die Strandfotos von Hunderten Freunden im Newsfeed.

- $\quad$ Bloß die Spatzen pfiffen in den Bäumen, und ab und zu hörte man das Klingeln einer Tram.

- Ehrfürchtig diskutierten die Besucher die verinnerlichte Szene, beobachteten lange, wie sich das kostbar gekleidete Mädchen in den Brief versenkt, und ließen sich keines der Details in dem spärlichen Interieur entgehen.

Similarly, "frame instance" is implemented in the professional discourse:

- Die Studien haben schon jetzt gezeigt, dass Personen, die mit einem adaptiven Tempomaten oder mit einem Assistenzsystem zur Spurhaltung fahren, viel mehr im Auto telefonieren und anderen Tätigkeiten nachgehen.

- Es wird es immer wieder Situationen geben, in denen der Fahrer eingreifen muss, weil die Automatik mit Dingen konfrontiert ist, für die sie nicht vorgesehen ist.

- Bei der Planung, Realisierung und Auswertung von ergonomischen Untersuchungen sind stets formale und inhaltliche Aspekte zu bedenken und eine definierte Reihenfolge des Abarbeitens zu berücksichtigen, wenn diese Untersuchungen valide(wahre, gültige), repräsentative(verallgemeinerungswürdige) und relevante (nützliche) Ergebnisse und Erkenntnisse zeitigen sollen.

Any perceptual situation exists in space. Verbalization of the categorical node "space" in everyday knowledge is characterized by the need to express objects that act as landmarks, as well as pointers, reflecting an orientation towards the observer.

- Nach einem Urlaub spürte ich Schmerzen in der rechten Wade.

- $\quad$ Er sieht von Weitem Plantagen voller Kirsch- und Apfelbäume, die in diesem Jahr keine Früchte mehr tragen werden.

- $\quad$ Über der gesamten Stadt liegt der leicht süßliche Geruch der Fischsoße Nuoc Mam, die in zahlreichen kleinen Betrieben entlang des Duong Dong Rivers produziert wird.

Similar language implementations of the frame top nodes in the cognitive situation can be noted when objectifying professional ideas:

- Die Operatoren sollen immer sicherstellen, dass die Diagnose des Umfeldes (im Cockpit und auch auf dem betrieblichen Arbeitsplatz) erfolgt ist.

- Die Kabinenbesatzungen arbeiten weltweit nach den Vorschriften der nationalen Luftfahrtbehörden.

The frame top node in the cognitive situation "result" is a coordinate with very diverse forms of linguistic manifestations. In ordinary knowledge, these can be physical and emotional reactions to obtained perceptual information, as well as descriptive or evaluative characteristics of the knowledge object:

- Und doch bekommt er Angst, wenn sein Kalender mal ein paar weiße Seiten zeigt.

- Im Frühjahr, o Mutter, erfüllt mich der Duft deiner Mangowälder mit wilder Freude...

- Ein gesunder Mensch spucke das entsprechende Gemüse wegen des bitteren Geschmacks jedoch in der Regel gleich wieder aus, erklärte die Expertin.

- Ein angenehmer Duft kam ihm entgegen, und es schaute die Dosen interessiert an.

The analysis of professional texts has shown that the "result" node has similar implementations in specific knowledge. In the examples below you can see both the emotional component of the activity of the cognizer and evaluativity in judgments:

- $\quad$ Ein Pilot soll angeblich einen Flug in die Türkei verweigert haben, weil er Angst um sein Leben hatte.

- Das schlimmste, wie Pilot Smith erklärte, was passieren kann, sei, die Kontrolle zu verlieren. 


\section{Research findings}

The stated theoretical positions and analysed examples allow us to draw the following conclusions.

The linguistic world view is a form of expressing knowledge of various personality type individuals. The way of verbalization in the language fragment of information about the cognitive situation indicates the peculiarities of everyday and professional world modelling. Depending on the sphere of communication, a person uses certain lexical and grammatical means to objectively express the informational and pragmatic aspects of a statement.

The question concerning the method of various types of knowledge conceptual structuring can be considered at the level of the utterance, which contains significant informational clusters necessary for the author of the statement to describe a particular state of affairs. The cognitive situation reflected in the consciousness is a unit of the mental coding level, considered as a frame.

The frame is a universal format for storing situational information that predetermines the awareness and structuring of new information and allows us to consider the cognitive process as a comparison of known and new information. This informational structure, the essence of which is reduced to the realization by a person of the way of obtaining knowledge, includes significant clusters of categorical meaning or so-called top slots some general ideas (rubrics) that change depending on the situation. The emergence of these categorical coordinates in various contexts indicates their universality for the process of thinking. The combination of such coordinates forms a kind of categorical net, in accordance with which a person, summarizing his experience, is aware of new information and objectifies it with the help of language means. Knowledge of the situation, therefore, is a kind of typical representation, a "frame prototype," a kind of support structure consisting of the mandatory top nodes - the basic ideas that reflect the segmentation of a certain type of situation. A "frame instance" is formed on the basis of a "prototype frame". Along with general categorical meanings, it includes their private implementations, which are recorded in the language fragment. Categories of ordinary knowledge, therefore, are generalizations of the categorical nodes of the frame of a cognitive situation.

The ways of verbalization of these general ideas vary depending on the situation described, the goals of communication, the individual characteristics of the person, etc. One of the ways to identify such options is to analyse means of expressing knowledge about the cognitive situation in everyday and professional discourse.

\section{Conclusion}

The analysis of the main categories reflected in various texts showed both general and specific characteristics in their objectification.

The general patterns of expression in the text of everyday and professional knowledge include the verbalization of the space-time framework of the cognitive situation, as well as the categorical coordinates associated with the result of human cognitive activity. The objectification of other coordinates in professional knowledge has its own characteristics: when naming a subject, the need to clarify its social and professional status is noted; the categories "object" and "instrument" are characterized by the realization of knowledge about technical devices and installations. The semantic knot "cognitive action" most often reflects mental operations. The language expression of the considered categories in everyday knowledge is more focused on the cognizer: the nominations of people and animals often fill semantically the "subject" node. The object is any element of reality a person deals with every day; the categorical meaning of "cognitive action" is realized in verbs with the meaning of perception; the organs, responsible for the perception of information of various modalities, act as tools.

Summing up, the unity of the categorical representation of knowledge demonstrates the categorical net universality, with the help of which the experience of a person is structured. The difference is determined by the need of results verbalization accuracy for professional knowledge, and by the possibility of the subjective opinion expressing - for the everyday one.

\section{References}

1. Ju. N. Karaulov, Lingvisticheskoe konstruirovanie $i$ tezaurus literaturnogo jazyka (Nauka Publ., Moscow, 1981)

2. G. V. Kolshanskij, Logika i struktura jazyka (Vyssh. Shkola Publ., Moscow, 1965)

3. E. S. Kubrjakova Rol' slovoobrazovanija $v$ formirovanii jazykovoj kartiny mira [Rol' chelovecheskogo faktora $\mathrm{v}$ jazyke: Jazyk i kartina mira, 141-172] (Nauka Publ., Moscow, 1988)

4. R. I. Paviljonis, Problema smysla: sovremennyj logiko-filosofskij analiz jazyka (Mysl' Publ., Moscow, 1983)

5. A. Vezhbickaja, Jazyk. Kul'tura. Poznanie (Russkie slovari Publ., Moscow, 1996)

6. D. E. Rumelhart, Schemata: the building blocks of cognition [Theoretical Issues in Reading Comprehension] (Lawrence Erlbaum Associates Publishers, Hillsdale, NJ, 1980)

7. Ch. J. Fillmore, Novoe v zarubezhnoj lingvistike, 10, 369-495 (1981)

8. R. W. Langacker, International Journal Of Cognitive Linguistics, 1, 31 (2010)

9. V.L. Abushenko, Znanie [Novejshij filosofskij slovar': 3-e izd., ispravl] (Knizhnyj Dom Publ., Minsk, 2003)

10. I. T. Kasavin, Postigaja mnogoobrazie razuma (Vmesto vvedenija) [Zabluzhdajushhijsja razum?: Mnogoobrazie vnenauchnogo znanija] (Politizdat Publ., Moscow, 1990) 
11. A. A. Ufimceva, Rol' leksiki v poznanii chelovekom dejstvitel'nosti $i$ v formirovanii jazykovoj kartiny mira [Rol' chelovecheskogo faktora v jazyke: Jazyk i kartina mira] (Nauka Publ., Moscow, 1988)

12. E. I. Golovanova, Bulletin of the Chelyabinsk State University, 1, 32-35 (2013)

13. M. V. Tsyguleva,

H. V. Tsoupikova, M. A. Fedorova, I. N. Efimenko, Advances in Intelligent Systems and Computing, 907, 426-433 (2019)

14. Ju. D. Apresjan, Semiotika i informatika, 28, 5-33 (1986)

15. M. L. Minsky, Frame theory [P. N. Johnson-Laird and P. C.Wason, Thinking: Reasings in Cognitive Science] (Cambridge University Press, 1977)

16. G. G. Galich, N. J. Shnyakina, Procedia Soc Behav Scis, 206, 30-35 (2015)
17. A. V. Bondarko, $K$ voprosu o perceptivnosti [Sokrovennye smysly: Slovo. Tekst. Kul'tura] (Jazyki slavjanskoj kul'tury Publ., Moscow, 2004)

18. J. M. Sishchuk,

I. G. Gerasimova, M. A. Goncharova, Anthropocentric world picture in German and English geological and mining metaphoric terms [Innovation-Based Development of the Mineral Resources Sector: Challenges and Prospects - 11th conference of the Russian-German Raw Materials, pp. 555-560] (CRC Press, 2018)

19. M. R. Zheltukhina, M. V. Busygina, M. G. Merkulova, I. A. Zyubina, L. M. Buzinova, Xlinguae, 11, 639-654 (2018).

20. A. Klyoster, G. Galich, Procedia Soc Behav Scis, 206, 56-61 (2015)

21. N. V. Gorokhova, I. N.Kubyshko, Astra Salvensis, 6, 625-630 (2018)

22. Yu. Kobenko, E. Tarasova, Procedia Soc Behav Scis, 206, 3-7 (2015) 